\title{
Failure of Public Infrastructure Projects in Nigeria: Causes, Effects and Solutions
}

\author{
Article by Nnamdi Nweze \\ Ph.D in Management, Texila American University, Nigeria \\ Email: nemeka@texilaconnect.com
}

\begin{abstract}
The Nigerian landscape is littered with thousands of failed Public Infrastructure Projects, many of them costing the government billions of naira and denying the citizenry access to quality infrastructure which is critical for a decent standard of life. This study was undertaken to assess the rampant failure of Public Infrastructure Projects in Nigeria, with a view to determining its causes and effects, and proffering possible solutions to the menace. Findings from the study revealed ten major causative factors of infrastructure project failure. The study was conducted using qualitative research-based content analysis in which information was essentially generated from available literature sourced from reputable publications. The study concluded by recommending workable solutions to drastically reduce or completely eliminate the problem.
\end{abstract}

Keywords: Project Failure, Public Infrastructure, Project management, Cost and Time Overruns, Contract Procurement.

\section{Introduction}

The Federal Republic of Nigeria commonly referred to as Nigeria is a federal constitutional republic in West Africa. With approximately 184 million inhabitants, Nigeria is the most populous country in Africa and the seventh most populous country in the world. In 2014 Nigeria became the biggest economy in Africa with a nominal GDP of $\$ 587 \mathrm{bn}$, overtaking South Africa to become the world's $20^{\text {th }}$ largest economy. Nigeria is viewed as an emerging market by the World Bank and has been considered as a regional power on the African continent. Extensive hydrocarbon deposits and a rapidly growing population are attractive features drawing the attention of foreign investors to Nigeria. It is estimated that Nigeria currently accounts for 45 percent of the total \$360bn in household consumption expenditure across 11 sub-Saharan countries, which were used as a proxy to study the continent.

Regrettably however, Nigeria still faces significant challenges with the appalling state of its infrastructure. From power supply and housing to roads and rail lines, and from irrigation systems and water pipelines to mobile and broadband networks, Nigeria's infrastructure supply is grossly inadequate. Research findings indicate that Nigeria's essential infrastructure stock is estimated at about 20-25 percent of GDP whereas usual level for middle income countries of Nigeria's size is around 70 percent according to Ousmane Dore, country director of African Development Bank (AfDB) in Nigeria.

The impact of infrastructural deficit on the macro economy and on the quality of life in Nigeria is severe. For example, Nigeria grew at 5.4 percent in 2013, but AfDB projects that its growth rate would be about 2 percent higher with adequate infrastructure in place. Poor infrastructure constitutes a huge burden on both foreign and local businesses, given the difficulties involved in accessing markets through bad roads or dilapidated ports coupled with the high cost of procuring and maintaining private electricity generators for industrial and commercial purposes. Poor infrastructure leads to post harvest losses of as much as 40 percent which ultimately decimates the purchasing power of millions of farmers. It also hinders industrialization and manufacturing, thereby hampering job creation and poverty reduction. Conclusively, this situation has led to a hostile environment for doing business, low national productivity, 
poor living standard, a lean industrial base and overdependence on imported goods which encourage poverty, unemployment and consequently underdevelopment.

Several factors are responsible for the current state of public infrastructure in Nigeria, chief among them is the rampant failure of otherwise well intentioned infrastructure projects over the years and the seeming incapacitation of public sector administrators to tame the menace of project failure. According to the 2011 report of the Abandoned Projects Audit Commission, an estimated 11,886 federal government infrastructure projects failed in the last 40 years across the country.

In a bid to uncover the reasons for the abysmal performance of the Niger Delta Development Commission, a presidential monitoring committee was set up by the federal government to review the activities of the commission. Findings from the review showed that of the 609 infrastructure projects monitored, 285 projects representing approximately 46.8 percent failed at various levels of implementation.

Project failure may be defined as inability to complete a project in line with cost, time and quality specifications or inability of a project to satisfy the expectations of its sponsor (Amachree, 1988). Based on the foregoing definition, it is clear that Nigeria's landscape is littered with projects that failed to fulfill their intended purposes, with many of them unable to achieve completion after several years, thereby making some of them obsolete and funds expended on such projects have become a waste.

Variation in project cost may be unavoidable in some cases due to inflation and other unforeseen events but poor conceptualization and design have also contributed to the inability to make realistic estimates of cost of materials and cost of the entire project. Corrupt public officials and contractors have continued to exploit this lacuna to their advantage such that variations end up taking the cost of projects several magnitudes higher, most times leading to the failure of such projects. This is particularly common in road construction projects as initial excavation and grading work are sometimes stopped midway, thereby worsening the state of such roads and inflicting hardship on the rural or urban communities served by the roads, with attendant negative impact on the economic fortunes of those who use the roads on daily basis.

The questions then arise: what are the causes of frequent public infrastructure project failure in Nigeria? What are the effects of these failed projects on the Nigerian economy? And what are the possible solutions to incessant failure of public infrastructure projects in Nigeria?

Considering the level of devastation often caused to various parties involved in infrastructure project execution in Nigeria, it is imperative to examine relevant factors contributing to the failure of such projects. The objectives of this study is to identify the causes of failure of public infrastructure projects in Nigeria, to explore the effects of public infrastructure project failure on the economic development of Nigeria and to proffer workable solutions to the problem.

The study is significant because a reduction in failure rate of infrastructure projects will result in stable power supply, improvement in broadband quality, good roads, bridges, dams, railways, etc., for the benefit and well being of Nigerians and the enhancement of Nigeria’s economic fortunes.

\section{Review of existing literature}

Over the years, Nigeria has been characterized by military dictatorships, corruption and mismanagement which led to extended periods of economic stagnation, high poverty levels and decay in public infrastructure (Okonjo-iweala and Osafo-kwaako, 2007). The lack of consistent upgrade of public infrastructure and the failure of several infrastructure projects have also led to severe infrastructural challenges with serious adverse effect on private sector activities.

But attempts to gain a clear understanding of the concept of project failure have been difficult. With the unending debate over what constitutes success, it is understandable why the concept of failure or lack of success has become very contentious. Pinto and Mantel (1990) are of the opinion that the difficulties associated with crafting a proper definition of project failure could be attributed to a general lack of 
consensus of the concept, absence of credible empirical studies on the systematic causes of failure, the taxonomy of project failure and the life cycle of a project.

Although projects are said to have failed when they fail to meet their budgeted cost, time, scope or quality, Ika (2012) however insists that projects may be completed within their estimated time and cost, and to the specified scope and quality but still be regarded as having failed essentially because the definition of project failure is influenced by how failure is defined among the project stakeholders, the nature of the project in question and the stage under review in the life cycle of the project. It is therefore crucial to look beyond the existing criteria of time, cost, scope and quality when seeking to determine whether a project has failed.

Factors such as the aspiration and satisfaction of stakeholders, benefits to the community or project sponsor should be considered when determining the status of a project in terms of success or failure. Nelson (2005) support this view by arguing that project usefulness, value to society and learning potential should be of utmost concern when evaluating the status of a project. Project failure therefore exceeds the inability of a project to meet its stipulated targets; it includes the failure to satisfy the goals of stakeholders in terms of functionality and post-completion performance.

The functionality goals, ecstatic values and stakeholder satisfaction often envisaged at the commencement of infrastructure projects in Nigeria have not been realized in majority of public interest projects scattered across Nigeria because of incessant project failures (Ayodele and Alabi, 2011). Over thirty years ago, Osemenan (1987) posited that Nigeria has become the world's junk-yard of failed projects estimated at billions of naira while years later, Kotangora (1993) further buttressed the fact by stating that there are about 400 failed projects costing in excess of three hundred billion naira located across Nigeria. This number has since escalated.

Review of existing literature on the subject of public infrastructure project failure indicates that corruption, absence of project management expertise, inexperienced personnel and absence of relevant skills are some of the reasons for the failure of most public sector projects in Nigeria. Specifically, a study conducted by Olalusi and Otunola (2012) revealed that incorrect estimation, insufficient planning, lack of risk management know-how, dearth of skilled personnel, poor knowledge of the work requirement as well as corruption are some of the key reasons for the failure of public projects in Nigeria. Similarly, Oyewobi, Ganiyu, Oke, Ola-awo and Shitu (2011) stated that the causes of unprofessional project management practices in Nigeria are attributable to corruption and financial gratification.

Furthermore, Igbokwe-Ibeto (2012) studied factors affecting local government infrastructure projects in Nigeria and concluded that corruption, delays in budget releases, delays in payment of performance certificates, community eruption, labour unrest, inaccurate assessment of the project environment and contractor incompetence are the fundamental causes of project failure in Nigeria.

Many scholars have also cited inconsistency in government policies as one of the major causes of infrastructure project failure in Nigeria. Policy inconsistency in this regard mainly refers to frequent changes in leadership (Efenudu, 2010), which brings about discontinuation of existing projects and programmes, and the resort to self-conceptualized projects. Although this was more common during the military era, democratic governments in recent years have however continued to practice this antidevelopmental tendency with attendant adverse implications for Nigeria's infrastructural and economic development.

Ubani et al (2010) performed a research to determine variation factors of project plans and the role of such factors in the failure of projects in Nigeria. The study identified design errors, management challenges and resource allocation difficulties as the prominent variation factors which significantly contribute to infrastructure project failure in Nigeria. Considering the emphasis being laid on inadequate budgetary provision and insufficient resource allocation, it is pertinent to highlight the provisions of Section 4 (2) (b) of the Nigerian Public Procurement Act 2007 which stipulates that 'all procurement shall be based only on procurement plans supported by prior budgetary appropriations; and no procurement proceedings shall be formalized until the procuring entity has ensured that funds are available to meet the 
procurement obligations. This means therefore that contracts should only be awarded if funds are available at the procurement stage, implying that inadequate budgetary provision should not be a reason for project failure in Nigeria, but according to several researchers including Ewa (2013), numerous government infrastructure projects have failed due to paucity of funds.

But the fact however remains that variation of costs often render all initial funding arrangements put together for a project useless as an increase in costs ultimately makes available funds inadequate for the completion of the project. Akindoyeni (1989) observes that there is the penchant for some designers to make adjustments during design in order to please the client without taking into consideration the effect of those adjustments on the project cost and schedule. He further categorized changes as either project development changes or scope growth changes. Project development changes are changes which are required to implement the scope as presently defined, while scope growth changes are changes that completely modify the projects original scope which is the scope that was approved prior to the commencement of the design phase. These changes though unavoidable sometimes, usually add cost and time to the previous design which eventually pose serious threats to the success of the project.

Another cause of infrastructure project failure in Nigeria aside from variation occasioned by inadequate scope description and documentation is the reluctance (usually midway into the project) of financial institutions involved in providing funding to contractors to make such funds available due to the fear and possibility that the project might not be implemented as envisaged, thereby stalling the project.

The literature review conducted exposed issues of serious concerns which hamper the successful completion of public infrastructural projects in Nigeria and these issues must be addressed if Nigeria's infrastructure stock is to be expanded because there is ample empirical evidence linking a nation's infrastructure capital with its growth potentials (PWC, 2004). It is for this reason that this paper seeks to conduct a qualitative examination of the causes and effects of public infrastructure project failure in Nigeria, with the aim of proffering solutions which will ensure that all relevant factors necessary for successful infrastructure delivery are identified, harnessed and integrated to ensure infrastructure base for Nigeria.

\section{Research methodology}

The aim of this study was to evaluate the subject of public infrastructure project failure in Nigeria. To properly deliver on this, a qualitative research method using content analysis was considered most suitable. Qualitative research holds the notion that understanding a phenomenon or situation or event comes from exploring the totality of the situation usually through available hard information. Qualitative content analysis on the other hand is a readily understood, unobtrusive and inexpensive research method which does not require contact with people, and is regarded as the most easily replicable research method coupled with the ease with which reliability could be established particularly when considering trends over a period of time.

The subjective and perceptive nature of the subject under consideration required the interpretation and description of what constitutes project failure. Afterwards, documentary analysis was conducted through in-depth review of text books, academic journals, conference proceedings, organizational publications and relevant websites. Information obtained was analyzed by adopting the following steps: organizing the information; categorizing the information, building of themes and patterns, understanding emerging concepts and writing up. The philosophical consideration behind the choice of this method may be viewed from two broad perspectives. The first is linked to the essential requirement of investigating infrastructure project failure in Nigeria. The second is linked to the need to select a research strategy that enabled the collection of rich qualitative information. The findings were presented based on emergent themes from the analysis.

\section{Result and discussion}

Ten recurring themes were identified as factors responsible for infrastructure project failure in Nigeria during the course of this research. The recurring themes are discussed below: 
Poor project management and inefficient resource allocation: The lack of sound Project Management by sponsors or contractors often lead to construction delays and extra costs for both parties. In addition to the problems that occur during construction, poor project management had in the past resulted in a completed facility that failed to meet the specified quality and functionality requirements, failed to produce the intended products, or could not be operated for its intended life.

Most infrastructure projects in Nigeria have failed due to poor project management and ineffective resource allocation. Infrastructure development is a construction process whereby an organization assumes responsibility for a project, delegates a team to build it and initiates systems such as tools, equipment, processes and procedures with which the work can be completed. This dovetails into three fundamental elements requiring execution and control, which may be symbolized by 3 Ps: the project outcome (product), the tools, technology and management systems (process) and the team to deliver the project (people).

For a project to achieve its purpose, the systems have to be integrated and aligned so as to enable the people to carry out their functions efficiently. However, many construction companies in Nigeria engage in unprofessional practices that lead to project failure. Project managers sometimes hold overly optimistic views which results from inadequate analysis. This could affect the operational plan or the schedule plan or both. When the schedule is based on performance expectations from subcontractors and expected productivity from the workforce, meeting the schedule will depend on subcontractors meeting stated deadlines. When these targets are not met, previous unrealistic assumptions will therefore demand that the work plan be changed to recover from unexpected lapses which ultimately increases the potentials for project failure.

The penchant for fire brigade approach to project management in Nigeria is also a critical factor responsible for project failures. Project managers and government agencies often take on extremely aggressive schedules without outlining necessary plans, resources and systems to adequately address the difficulties which may arise. This forces project staff to work in areas outside their competence, thereby compelling them to take shortcuts and barely giving them necessary space to assess risks and plan for eventualities without which failure is almost inevitable. Buttressing this point, El-Rufai (2012) states as follows:

"Assume a road is to be constructed between two locations, the rights-of-way must be surveyed, levels taken, alignment finalized, road designed, and detailed drawings, bills of quantities and other bidding documents prepared prior to inviting pre-qualified engineering contractors to submit competitive tenders. The design development process can take anything between some months to more than a year, while it takes a minimum of 5 months from advertising invitations for bids to presentation to the FEC or other approving authority. This suggests that design and procurement processes for any project ought to start at least a year or two before being budgeted for. This only happens in a few foresighted agencies (MDAs).

Typically, nothing happens until the budget is passed and cash-backed, then the implementing MDA begins the fire brigade work of compressing this timeline into a few weeks! Most MDAs wait until projects are included in budget or the budget passed before they start project surveys or design or the procurement process. When an MDA spends at least 5 months on procurement, how much time does the contractor have to execute the project and draw down the funds before the financial year runs out? This becomes a big issue as MDAs are required by law to return all unspent funds to the treasury by the year end".

Evaluation of risks during project development tends to receive inadequate attention due to time constraints and the urgency to deliver, eventually leading to the likelihood of higher risks being imposed on the project. When a project is denied the very necessary processes and preparations which enhance the possibility of success, such a project tends to fail and this has been the case in Nigeria.

Lack of financial capacity and delays in payment: Public infrastructure projects also fail in Nigeria due to paucity of funds either on the part of contractors or on the part of government, this is more so given that government ministries, departments and agencies are required to return unspent budgeted funds to the 
central coffer at the end of every financial year. This practice often leaves MDA's stranded for cash to complete on-going projects.

Notwithstanding the adverse implications of not exhausting funds budgeted for implementing infrastructure projects on the economy, MDA's are always eager to showcase their incorruptibility by rushing to return unspent funds, thereby promoting project abandonment and failure. Government at all levels in Nigeria have failed to conduct an evaluation of the infrastructural projects for which budgeted funds are being returned to realize the incompetence aspect of government agencies in terms of time wasted on procurement which causes delay and project failure as all unspent funds must be returned to government at the end of every financial year.

The current accounting system for funds cannot be deemed to be adequate without accounting for other project inputs such as time, human and material resources which are wasted by MDA's in the course of project procurement, thereby leaving contractors in a dilemma when the financial year ends in the middle of a project. The amount of unspent funds expected by government in 2008 alone was estimated at over N500 Billion (i.e. about US\$3 Billion) according to Ademuyiwa, et al (2009).

On the part of contractors, several contracting companies in Nigeria do not have the financial capacity to execute the contracts they secure and this leaves them stranded for funds midway into the project. Section 63 (1) of the Public Procurement Act states thus: 'In addition to any other regulations as may be prescribed by the Bureau, a mobilization fee of no more than $15 \%$ for local suppliers and contractors and $10 \%$ for foreign suppliers and contractors may be paid to a supplier or contractor ...'. This implies that contractors must have the requisite capital outlay for project execution prior to submission of bid documents, but unfortunately this principle is not followed by MDA's, thus contributing to project failure in Nigeria.

Bureaucracy, corruption and inaccurate cost estimate: The Nigerian public service is characterized by a very high level of official bureaucracy which seriously hinders infrastructure delivery in Nigeria. This bottleneck is prevalent in the areas of appropriation, procurement, documentation, approvals and fund release. Given that government agencies are often charged with the responsibility of initiating and monitoring on-going projects, officials capitalize on this authority to exploit the process by conniving with contractors to manipulate cost estimates and document false progress report to favor contractors, and receive kickbacks, thereby ensuring the failure of most infrastructure projects.

Bribery and corruption are regarded by most Nigerians as a custom even with the ongoing crusade against corruption since the return to democracy in 1999. Delays and cost overruns are part of the consequences of excessive bureaucracy and corruption, for instance contractors often purposely overstate the time and cost requirements of a project, falsify time sheets, utilize cheaper or defective materials and sometimes deliberately omit specifications in order to reap illegitimate financial benefits (Sohail and Cavil, 2009). Further stressing the impact of excessive bureaucracy and corruption on project development, Szeffel (1998) is of the opinion that corruption alters the capacity for institutional performance in the context of administrative efficiency, undermines managerial effectiveness and redirects resources from regional, country and global development to individual interest.

The role of corruption in project failure in Nigeria is so severe to the extent that in an effort to ensure the success of bids submitted; contractors sometimes buy out information from the client quantity surveyor to ensure that the lowest tender figure is submitted (Odeyinka and Yusuf, 1997). The effect of this is that infrastructure projects are often awarded to companies which do not have the technical capability to deliver on the project. Such practices have been found to be responsible for so many failed projects.

Contractor Non-performance and deficient contracting practices: Another recurring theme in this study was the issue of deficient contracting practices in Nigeria and frequent cases of contractor nonperformance. A major factor linking both subjects and which has caused immense harm on Nigeria's infrastructural development is nepotism. Nepotism and tribalism has significantly undermined Nigeria's 
contracting process such that the best contractors do not always get the job, rather contracts are awarded based on ethnic and sectional considerations, resulting in many failed projects.

Equally, contracting practices in Nigeria is highly deficient. Usually, a contract document should contain every aspect of the job to be done and this should include payment terms, pricing, service levels, etc. This has not been the case in Nigeria. Several cases exist of projects that failed because the entire project scenario was not captured in the original contract documentation and as such disputes could not easily be resolved. The absence of relevant specifications in the contract tends to encourage disagreements followed by prolonged negotiations and avoidable change orders which entail new budgets and schedule, practically leading to delays, cost overrun and failure.

Most government agencies in Nigeria lack an ethical tender system which should ordinarily assist in developing a draft of the most suitable contract type for the specific project taking into cognizance the peculiarities of the envisaged project. The absence of such a tender system which should explicitly define the terms and conditions that would govern the project and spell out penalties in the event of delays, in addition to specifying the party that would bear cost overruns has led to a situation whereby contractors tend to be at ease with their non-performance knowing that there are no means of checkmating their unprofessional activities. The use of generic contract templates in contract administration in Nigeria also contributes to project failure as no preparation is made to envisage and tackle operational challenges when they arise.

Lack of experience, knowledge and technical competence: The construction industry in Nigeria is suffering from an acute shortage of skilled manpower. This is because Nigeria has been experiencing brain drain for some decades, with highly skilled personnel migrating to developed countries in search of more rewarding opportunities. The consequence of this trend is that Nigeria has had to depend on expatriates from other countries to execute infrastructural projects. This comes at highly exorbitant costs and poses a major challenge to government's quest to implement high impact projects which are often complex.

Also within the country, there has been a huge movement of construction professionals from public to private sector and this limits the capacity of government agencies to properly oversee project development, with government now having to rely mainly on the services of private consultants whose services constitute a huge financial burden on government. A critical contributory factor to infrastructure project failure is therefore the inability of local professionals and government personnel to deliver on highly complex projects even when they give the project their best, owing to a huge skills gap which threatens the economic and technological advancement of the country.

Inadequate planning and poor scheduling: Infrastructure projects in Nigeria are hampered by inadequate planning and poor scheduling. Any project that is not well planned is bound to fail (Westerveld, 2003). Project planning helps the project team to develop objectives and outlines the best way of achieving them. Parties to infrastructural project implementation in Nigeria often put in place inadequate plans before commencement of work and also tend to use inexperienced professionals in project planning, with dire consequences on the project. Even when there are capable people to draw up the project plan, time constraints arising from a variety of factors make it difficult for planning officials to follow pre-established guidelines and deliver an implementable plan that would guarantee the success of the project.

Under normal circumstances, a project should have a budget and deadline prior to take-off but in many cases, project managers commit to low estimates without knowing it and as such the project kicks off without the requisite material and resource outlay only for the budgets and deadlines to be overshot before the project team comes to the realization that adequate planning was not carried out. In this regard, poor planning and lack of agreement on project outcomes impact negatively on the execution phase of most infrastructure projects in Nigeria. Conflicting instructions from different government officials and frequent intra-governmental confrontations also causes unplanned adjustments to projects and has led to the failure of many infrastructure projects. 
Texila International Journal of Management

Volume 2, Issue 2, Dec 2016

Poor monitoring and scope tracking: Scope is the term used to describe the totality of deliverables expected at the end of a project. All project implementation plans, cost estimation, schedule, quality specifications and baselines are normally articulated based on the initial project scope. This implies that any change in project scope during execution will affect the whole project plan and would require a reviewed budget, schedule and quality. Whenever a change in scope occurs, scarce project resources are diverted to activities that were not part of the original scope, leading to pressure on the original schedule and budget. An evaluation of failed infrastructure projects in Nigeria indicate that project scope change usually arises from wrong initial scope definition, unanticipated risks and uncertainties and sudden change in financing which leads to change requests and then change in expected deliverables which also affects the whole project team.

Many times, poor scope management has caused dispute and litigation which impacts negatively on the project in terms of delays and cost overruns and could sometimes end in discontinuation of the project. Most construction companies in Nigeria do not integrate a suitable change management plan which enables the adoption of a proactive approach in managing the needs of stakeholders throughout the project life cycle. Such companies are therefore unable to select the key success factors together with the client, which accounts for their inability to establish KPI or milestones to measure the performance of the project scope. Sometimes, changes are communicated in an untimely manner which introduces confusion amongst the project team and eventually lead to project delay, abandonment or failure.

Poor design, frequent design changes and design error: Other major reasons for infrastructure project failure in Nigeria include errors in design, defective design and frequent changes in design. Given that design is the core basis for the implementation of a project, errors in design means that the project is bound to fail as the execution team may apply wrong techniques for achieving wrong deliverables and any effort to correct the mistake midway into the project is likely to increase costs and cause delays which could bring about project failure.

Many other projects have also failed in Nigeria because designs were done without proper assessment of site conditions and during the course of the project, the actual site conditions often poses a challenge to the construction team, necessitating additional work, revision of project scope and sometimes total contract revision. This often creates an obstacle to the success of the project and has led to project failure in cases where it was not well managed.

Most construction companies operating in Nigeria have been found to lack value management skills which are integral in obtaining the best cost effective design options while guarantying quality and outcomes that meet the expectations of project stakeholders, and this has significantly contributed to the failure of many projects.

Political instability and community interference: The lack of continuity in government policy has also been of adverse effect on Nigeria's infrastructural drive. History has shown that successive governments in Nigeria tend to discontinue projects started by their predecessors (Fubera, 1985). The underlying reason behind this trend is that contracts are usually awarded to cronies and such contracts are awarded purely to serve political purposes. As infrastructure contracts are normally inflated, incoming governments prefer to initiate their own projects and receive kick-backs rather than continue funding existing projects (Nwachukwu, 1988). This discourages private sector participation in infrastructure development in Nigeria.

There are other politically related reasons for discontinuation of projects in Nigeria and this includes rising inflation which affects the price of raw materials and increases the funds required to complete a project several fold following changes in government. When the cost of such projects are reviewed upwards many times by successive governments, such that the amount of money required to complete them is much higher that the amount required to deliver a new project, the tendency is to abandon them, hence such projects are regarded as having failed.

Communities playing host to projects often play a vital role in its success or failure. Such communities sometimes sabotage the project by making various kinds of demand from government and contractors. 
Construction companies are sometimes required to appoint indigenes of the community as subcontractors or to include influential community leaders on the payroll of the company even when such persons are not meant to perform work of any kind during the project. Failure to meet these litany of demands sometimes lead to disruption of on-going work, vandalization of equipment, theft of materials and abduction of expatriate workers by community youth groups. This attitude by host communities has put a stop to many infrastructure projects in Nigeria.

Poor communication and leadership: Poor communication and leadership between government agencies in Nigeria and contractors has been found to be of detrimental effect on many projects and has caused revocation of contracts by government, with attendant litigation which has led to the termination or failure of a number of projects. Effective communication is necessary for the success of any project. Sound communication practice helps to enhance team work and ensure better collaboration whereas poor communication results in misunderstanding, delays and disputes.

There are many hindrances to effective communication in the Nigerian construction industry and these include: unclear communication objectives, unclear channels of communication, ineffective reporting system and ineffective communication between the key parties involved in a project. Because construction is a highly fragmented, dynamic and dissimilar sector, effective communications is vital for the success of projects in terms of performance objectives such as productivity, profitability and re-work opportunities (Dainty et al, 2006). Project details are communicated by means of drawings, contract documents, addenda and specifications; hence the absence of vital tools and medium for effective communication has impacted negatively on the construction industry in Nigeria and accounts for many failed infrastructure projects.

\section{Conclusion and recommendations}

\section{Conclusion}

As has been shown in this paper, Nigeria is battling with the problem of infrastructure project failure, with devastating impact on Nigeria's infrastructure development quest. The root causes of rampant infrastructure project failure have been identified and include:

- Poor Project Management and Inefficient Resource Allocation

- Lack of Financial Capacity and Delays in Payment

- Bureaucracy, Corruption and Inaccurate Cost Estimate

- Contractor Non-performance and Deficient Contracting Practices

- Lack of Experience, Knowledge and Technical Competence

- Inadequate Planning and Poor Scheduling

- Poor Monitoring and Scope Tracking

- Poor Design, Frequent Design Changes and Design Error

- Political Instability and Community Interference

- Poor Communication and Leadership

Unarguably, the above mentioned causes of infrastructure project failure are interwoven in such a manner that one single causative factor dovetails into another thereby throwing up a gamut of seemingly intractable challenges to Nigeria's infrastructural growth, which requires concerted institutional reforms to eliminate.

\section{Recommendations}

In order to drastically reduce cases of infrastructure project failure in Nigeria, it is recommended that the following concrete measures be taken:

- Government must review Nigeria's procurement laws such as the Public Procurement Act 2007 and plug leakages leading to abuse of the procurement process by both government officials and contractors. 
Texila International Journal of Management

Volume 2, Issue 2, Dec 2016

- Relevant government agencies such as the Bureau of Public Procurement (BPP), National Council on Public Procurement (NCPP) and the Due Process Office which are the authorities charged with the responsibility of overseeing and monitoring federal government projects across the country must be sanitized and revamped to optimally discharge their functions devoid of sharp practices.

- The existing practice whereby Ministries, Departments and Agencies of government are required to return unspent budgeted funds at the end of each financial year must be reviewed with the aim of making adequate provisions for on-going projects started late in the year due to time spent on planning and procurement.

- Mechanisms should be developed to sanction erring contractors and hold construction companies to account for non-performance and failure to deliver after contracts have been awarded. This will serve as a deterrent to contractors who are in the habit of bidding for jobs for which they lack competence and also guarantee that companies seeking infrastructure contracts are adequately staffed for the job.

- Professional associations and statutory regulatory bodies in the construction sector such as the Council for the Regulation of Engineering in Nigeria (COREN), the Nigerian Society of Engineers (NSE), the Nigerian Institute of Quantity Surveyors (NIQS), etc., must initiate and enforce existing codes of conduct to ensure strict adherence of members to the highest standards of ethics and professionalism.

- Governments at Federal, State, and Local levels must quickly address unbridled corruption, nepotism and widespread community interference in the award of contracts, while efforts must be made to ensure that Nigerians receive the best value for their money in the context of infrastructure contract award and execution.

\section{References}

[1] Ademuyiwa, B., Akintola, K. and Akpe, A. (2009) 20,000 Projects Scuttled as MDA's Return N350 Billion Unspent Funds. Business Day, Vol. 7 (No. 529), 19 January, 2009: 1 and 4.

[2] Akindoyeni, A. (1989). The management of abandoned project. Journal of Nigeria Institute of Building, 1(2), 27.

[3] Amachree, S. M. O. (1988) Investment Appraisal in Developing Countries. Avebury Gower Publishing Company Ltd., England.

[4] Ayodele, E.O. and Alabi, O. M. (2011) Abandonment of Construction Projects in Nigeria: Causes and Effects. Journal of Emerging Trends in Economics and Management Sciences (JETEMS), Vol. 2, Iss. 2, pp. 142-145.

[5] Bunu, I. (2011) Presidential Project Assessment Committee Report, The Punch Newspaper, may 20, 2013.

[6] Bureau for Public Procurement (2007). Public Procurement Act (Nigeria) 2007.

[7] Dainty, A., Moore, D. and Murray, M. (2006) Communication in Construction: Theory and Practice. Taylor and Francis, Oxford, UK.

[8] Efenudu, F. O. (2010) Causes and Effects of Abandonment of Project on Property Value; A Case of Port Harcourt. Unpublished First Degree Dissertation, Department of Estate Management, Faculty of Environmental Sciences, Rivers State University of Science and Technology, Nigeria.

[9] Ewa, U. E. (2013) Root Causes of Project Abandonment in Tertiary Institutions in Nigeria. Journal of International Business Research, 6(11), 149-159. http://dx.doi.org/10.5539/ibr.v6n11p149

[10] El-Rufai, N. (2012) The Tragedy of Abandoned Projects. http://www.nigeriavillagesquare.com/nasir-elrufai/the-tragedy-of-abandoned-projects.html Retrieved September 6, 2016.

[11] Fubera, B. A. (1985) Introduction to Business Management. University Press Ltd., Ibadan, Nigeria.

[12] Igbokwe-Ibeto, C. J. (2012) Issues and Challenges in Local Government Project Monitoring and Evaluation in Nigeria: The Way Forward. European Scientific Journal, 8(18), 180-195.

[13] Ika, L. A. (2012) Project Management for Development in Africa: Why Projects are Failing and What Can be Done About it. Project Management Journal, 43(4), 27-41. http://dx.doi.org/ 10.1002/pmj.21281 
[14] Kotangora, O. O. (1993) Project Abandonment in Nigeria. Nigerian Tribune Newspapers.

[15] Nelson, R. (2005) Project Retrospectives: Evaluating Project Success, Failure, and Everything in Between. MIS Quarterly Executive, 4 (3), 361-372.

[16] Nwachukwu, O.T. (1988) Strategic Management. University Press Ltd., Ibadan, Nigeria.

[17] Sohail, M. and Cavil, S. (2009) Public-Private Partnerships in the Water and Sanitation Sector, Water Management, Proceedings of the Institution of Civil Engineers, 163(WM4), pp.261-267.

[18] Szeftel, M. (1998). "Misunderstanding African Politics: Corruption and the Governance agenda" Review of African Political Economy 25 (76). 221-240.

[19] Odeyinka H.A. and Yusuf A. (1997): The causes and effects of construction Delays on cost of housing project in Nigeria. Journal of Financial Management and Property and Construction. 2,

[20] 31-41.

[21] Osemenan, I. (1987): Project abandonment. Newswatch Magazine. (1), 15.

[22] Olalusi, O., and Otunola, A. (2012) Abandonment of Building Projects in Nigeria: Review of Causes and Solutions, International Conference on Chemical, Civil and Environment Engineering.

[23] Okonjo-Iweala, N., \& Osafo-Kwaako, P. (2007). Nigeria’s Economic Reforms: Progress and Challenges. Retrieved from http://www.brookings.edu/ /media/Files/rc/papers/2007/0323globaleconomics_okonjo\%20iweala/2007032 3okonjo_iweala.pdf

[24] Ousmane, D. in Fdintelligence (2015) Nigerian Infrastructure: Building From the Base Up. http://www.fdiintelligence.com/Locations/Middle-East-Africa/Nigeria/Nigerian-infrastructure-building-from-thebase-up. Retrieved September 6, 2016.

[25] Oyewobi1, L., Okel, A., Ganiyul, B., Shittul, A., Isa, R., and Nwokobia1, L. (2011) The Effect of Project Types on the Occurrence of Rework in an Expanding Economy. Journal of Civil Engineering and Construction Technology, 2 (6), 119-124.

[26] Pinto, J. K. and Mantel, S. J. (1990) The Causes of Project Failure. IEE Transactions on Engineering Management, 37(4): 269-276.

[27] Ubani, E. C., Nwachukwu, C. C. and Nwokonkwo, O. C. (2010). Variation Factors of Project Plans and Their Contributions to Project Failure in Nigeria. American journal of Social and Management Sciences, 1(2): 141-149.

[28] Westerveld, E. (2003). The Project Excellence Model: Linking Success Criteria and Critical Success Factors. International Journal of Project Management, 21(6), 411-418. http://dx.doi.org/10.1016/S0263-7863(02)00112-6 